\title{
ESTIMASI ENERGI GELOMBANG LAUT MENGGUNAKAN SATELIT ALTIMETRI JASON-2 STUDI KASUS: SELATAN PULAU JAWA
}

\author{
Muhammad Rizka Arief Pratama ${ }^{1)}$, Lalu Muhamad Jaelani ${ }^{2)}$, Albertus Sulaiman ${ }^{3)}$ \\ 1) Jurusan Teknik Geomatika, FTSP, ITS, ${ }^{2)}$ Pusat Teknologi dan Inventarisasi Sumber Daya Alam (PTISDA), \\ ${ }^{3)}$ Badan Pengkajian dan Penerapan Teknologi (BPPT) \\ Email: Imjaelani@geodesy.its.ac.id
}

\begin{abstract}
Abstrak. Data tinggi muka air laut (SSH) sangat diperlukan untuk mengetahui kondisi permukaan laut di suatu perairan. Dari data tersebut dapat diketahui di antaranya kontur permukaan laut dan karakteristik gelombang permukaan yang dipengaruhi angin atau gravitasi. Pengembangan energi terbarukan sangatlah penting untuk membantu pasokan listrik Indonesia yang hingga saat ini masih bergantung terhadap fossil fuel (energi tidak terbarukan). Data tinggi muka laut ini dapat membantu Indonesia sebagai negara maritim dunia untuk mengeksplorasi potensi lautnya terutama dalam bidang energi. Altimetry Radar (Radar Altimetri) adalah salah satu jenis sensor penginderaan jauh yang sedang berkembang, dimana dapat memonitor dan memetakan tinggi permukaan air laut secara akurat dan efektif. Pengolahan data titik nadir satelit altimetri dapat dilakukan di aplikasi pengolah matriks, Matlab setelah mengalami proses pengolahan awal pada software BRAT. Dalam penelitian ini dilakukan pengolahan data satelit altimetry Jason-2 pada tahun 2012, dengan hasil menunjukkan bahwa pada bulan Januari 2012, di perairan Selatan Pulau Jawa, Samudra Hindia memiliki panjang gelombang dominan sebesar 2319,208 dan 4638,417 m dan periode sebesar 33,7480 dan 74,9808 sekon yang memenuhi syarat menjadi sebuah swell yaitu di antara 30-300 sekon. Terdapat 3 spot potensial yang memiliki estimasi energi gelombang laut cukup tinggi dibandingkan dengan daerah lainnya.
\end{abstract}

Kata Kunci: Jason-2; SSH; BRAT; Matlab; energi gelombang

\begin{abstract}
Sea surface height data (SSH) is needed to determine the condition of the sea surface in the waters. From these data it can be seen among the sea surface contours and characteristics of surface waves which affected the wind or gravity. Development of renewable energy is essential to help Indonesian power supply which still dependent on fossil fuel (non-renewable energy). This sea surface height data can help Indonesia as a world maritime country to explore its marine potential, especially in the field of energy. Radar altimetry is one type of remote sensing sensors are being developed, which can monitor and map the sea level accurately and effectively. Data processing altimetry satellite nadir point can be made in processing application matrix, Matlab after a pretreatment on BRAT software. In this research, data processing Jason-2 altimetry satellites in the year of 2012, the results showed that in January 2012 at the waters south of the island of Java, the Indian Ocean has a dominant wavelength of 2319.208 and $4638.417 \mathrm{~m}$ and the period between 33.7480 to 74.9808 second that meet the requirement of a swell that is between $30-300$ second. There were 3 spot with an estimated potential energy of sea waves is quite high compared to other regions.
\end{abstract}

Keywords: Jason-2; SSH; BRAT; Matlab; wave energy

\section{PENDAHULUAN}

Indonesia dengan luas lautan sebesar 5,8 juta $\mathrm{km}^{2}$ (Kementrian Kelautan dan Perikanan Republik Indonesia, 2013) memiliki potensi laut yang sangat besar dalam bidang perikanan dan energi. Namun kurangnya optimalisasi terhadap sumber energi terbarukan (renewable energy) di Indonesia membuat potensi laut Indonesia menjadi kurang diberdayakan. Salah satu faktor penyebabnya adalah kurangnya eksplorasi terhadap permukaan laut untuk tujuan pengembangan energi.

Energi gelombang laut memiliki potensi untuk memberikan sejumlah besar energi terbarukan untuk kebutuhan energi dunia. Kelangsungan hidup komersialisasi energi gelombang yang luar biasa, seperti yang telah diakui, memiliki tingkat pertumbuhan tercepat dibandingkan dengan semua 
sumber energi lainnya (AM Muzathik, 2011). Energi yang mempengaruhi permukaan lautan dan membentuk gelombang dengan besaran energi potensial dan energi kinetik yang secara matematis dapat dihitung besarannya.

Pembangkit energi listrik tenaga gelombang adalah salah satu opsi yang dapat dikembangkan setelah memperhatikan beberapa aspek, seperti tinggi dan kuatnya gelombang laut di perairan lepas pantai Indonesia yang berhadapan langsung dengan samudra dan secara matematis dapat dihitung besaran energi output-nya. Dalam hal ini dibutuhkan beberapa tahapan untuk mengetahui daerah potensial energi gelombang laut terbarukan dan estimasi besaran energi yang dapat dihasilkan. Dari penelitian yang dilakukan sebelumnya dapat diketahui bahwa daerah perairan lepas dan samudra memiliki potensi energi gelombang yang besar (Lewis, 2011). Perairan Selatan Pulau Jawa merupakan salah satu lokasi yang diprediksi memiliki potensi tersebut dan membutuhkan pemetaan energi gelombang laut.

Salah satu upaya pemetaan daerah potensial energi yang diakibatkan dari tinggi gelombang laut adalah menggunakan satelit altimetri. Prinsip dasar satelit altimetri adalah dengan memaanfaatkan selang waktu perambatan gelombang radar yang dipancarkan oleh satelit. Pantulan pulsa radar ke lautan digunakan untuk menganalisa tinggi permukaan air laut, sedangkan besar dan bentuk pulsa radar berisi informasi tambahan tentang karakteristik permukaan air laut.

Dalam penelitian ini, dilakukan sebuah studi estimasi energi di selatan Pulau Jawa Indonesia yang diakibatkan oleh gelombang air laut dengan menggunakan data satelit Jason-2. Diharapkan, penelitian ini dapat menjadi sumber referensi mengenai pemanfaatan satelit altimetri dalam penentuan awal daerah potensi energi gelombang laut yang dapat memudahkan pengembangan penelitian ataupun pengukuran ke depannya.

\section{METODOLOGI}

Lokasi penelitian ini adalah Selatan Pulau Jawa yang termasuk ke dalam wilayah perairan Indonesia ini salah satunya terbentuk akibat gaya gravitasi yang terletak pada koordinat geografis $7^{\circ} \mathrm{LS}-9^{\circ} \mathrm{LS}$ dan $104^{\circ} \mathrm{BT}-117,5^{\circ}$ BT. Pass (lintasan) dari satelit Jason-2 yang meng-cover seluruh perairan Indonesia sebanyak 36 pass, dapat dilihat pada Gambar 1 dan Tabel 1.

Penelitian ini memfokuskan Selatan Pulau Jawa sebagai lokasi utama penelitian dikarenakan kondisi lautan yang mendukung, ditandai dengan tingginya ombak dan angin di perairan tersebut. Penelitian ini menggunakan data SSH satelit altimetri Jason-2 sebagai data utama, dan serangkaian proses image processing seperti Fast Fourier Transform dan BandPass Filtering untuk mendapatkan estimasi energi gelombang laut. Tahapan penelitian sebagaimana dijelaskan pada Gambar 2.

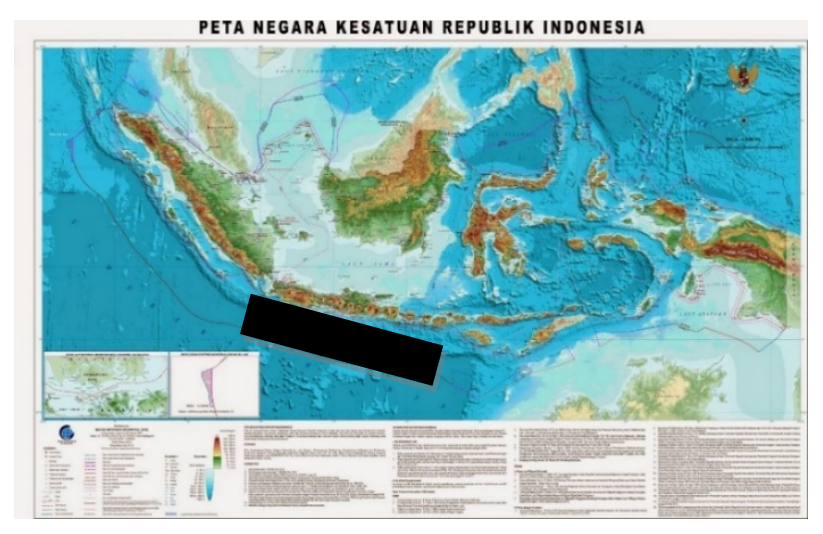

Gambar 1. Peta Negara Kesatuan Republik Indonesia (blok hitam adalah daerah penelitian)

Tabel 1. Pass (Lintasan Satelit Altimetri Jason-2 di Indonesia)

\begin{tabular}{cccccc}
\hline No. & Pass & Arah Pass & No. & Pass & Arah Pass \\
\hline 1 & 1 & Naik (ascending) & 19 & 138 & Turun (descending) \\
2 & 12 & Turun (descending) & 20 & 140 & Turun (descending) \\
3 & 14 & Turun (descending) & 21 & 151 & Naik (ascending) \\
4 & 25 & Naik (ascending) & 22 & 153 & Naik (ascending) \\
5 & 38 & Turun (descending) & 23 & 164 & Turun (descending) \\
6 & 49 & Naik (ascending) & 24 & 166 & Turun (descending) \\
7 & 51 & Naik (ascending) & 25 & 177 & Naik (ascending) \\
8 & 62 & Turun (descending) & 26 & 179 & Naik (ascending) \\
9 & 64 & Turun (descending) & 27 & 190 & Turun (descending) \\
10 & 75 & Naik (ascending) & 28 & 192 & Turun (descending) \\
11 & 77 & Naik (ascending) & 29 & 203 & Naik (ascending) \\
12 & 88 & Turun (descending) & 30 & 214 & Turun (descending) \\
13 & 90 & Turun (descending) & 31 & 216 & Turun (descending) \\
14 & 101 & Naik (ascending) & 32 & 227 & Naik (ascending) \\
15 & 103 & Naik (ascending) & 33 & 229 & Naik (ascending) \\
16 & 114 & Turun (descending) & 34 & 240 & Turun (descending) \\
17 & 125 & Naik (ascending) & 35 & 242 & Turun (descending) \\
18 & 127 & Naik (ascending) & 36 & 253 & Naik (ascending) \\
\hline
\end{tabular}




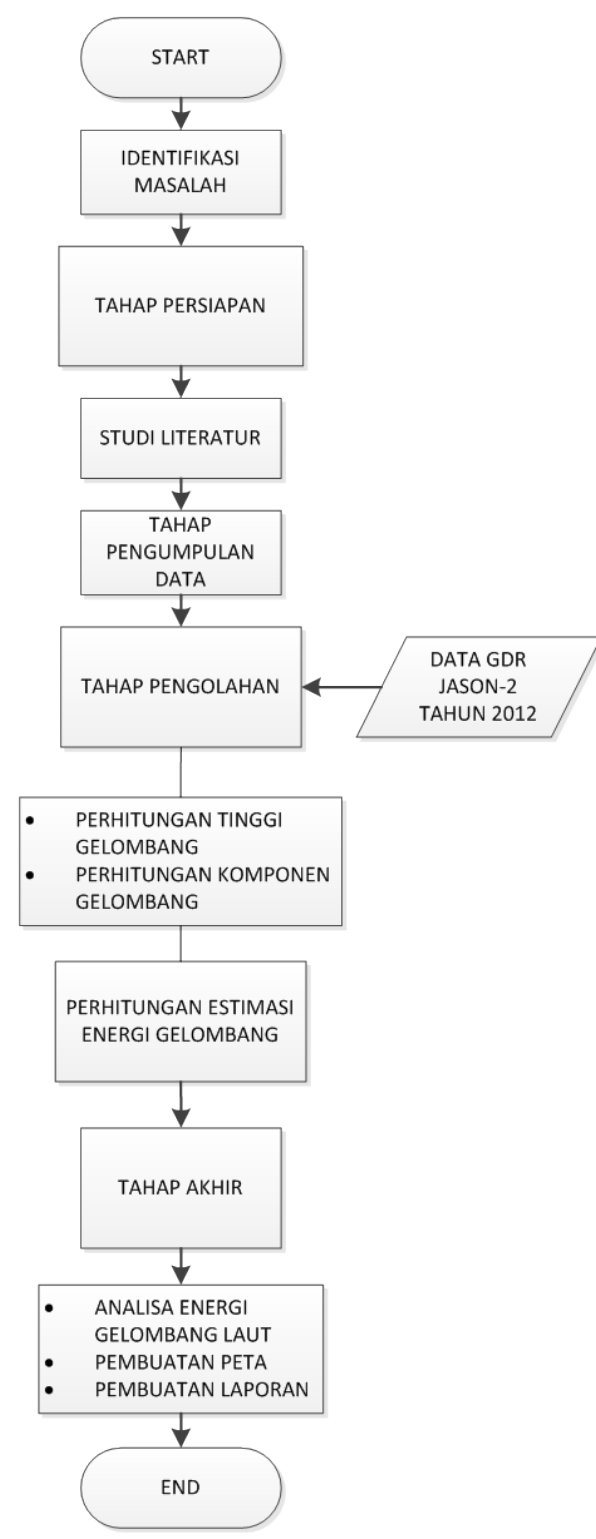

Gambar 2. Diagram Alir Penelitian

\section{Pengumpulan Data}

Pada tahap ini, dilakukan pengumpulan data yang berupa data mentah yang terkait dengan penelitian estimasi energi gelombang dan $\mathrm{SSH}$ wilayah perairan Indonesia pada bulan Januari 2012.

\section{Pengolahan Data}

Pada tahap ini, dilakukan pemilihan terlebih dahulu terkait cycle dan pass yang melewati lokasi penelitian, serta menyeleksi data yang dibutuhkan untuk mendapatkan data tinggi muka air laut. Semua data yang didapatkan pada proses pengumpulan data di atas, selanjutnya diproses menggunakan aplikasi BRAT. Tahap berikutnya adalah konversi dari data mentah Jason-2 menjadi data level-2 dalam ekstensi ASCII agar nantinya dapat diolah. Setelah dilakukan konversi data, dilakukan proses kontrol kualitas yang berguna untuk mendapatkan data yang baik sesuai kriteria. Kemudian dilakukan perhitungan terhadap SSH.

Proses griding dan interpolasi area yang tidak ter-cover sebelum pada akhirnya dilakukan pengolahan data untuk mengetahui komponen gelombang dan estimasi energi gelombang menggunakan aplikasi Matlab. Pada SSH dilakukan proses Fast Fourier Transform dan Band Pass Filtering untuk mendapatkan panjang gelombang dominan dari data dan juga periode dominan dari gelombang air laut yang terdeteksi di citra satelit Jason-2. Rumus-rumus yang digunakan dalam makalah ini adalah sebagaimana ditunjukkan oleh rumus 1 berikut.

$$
\sigma^{2}=g k \tanh k h
$$

$$
\begin{gathered}
\text { Di mana } \sigma \text { (sekon) merupakan periode gelombang, } \\
\text { k (konstanta) merupakan bilangan } \\
\text { gelombang, dalam hal ini adalah } 2 \pi / \text {, } \\
\text { g serta } \mathrm{h} \text { adalah gravitasi dan kedalaman } \\
\text { laut. }
\end{gathered}
$$

Nantinya kedua hasil tersebut akan sangat penting dalam proses penentuan significant Waveheight dan penentuan batas band-pass filter. Dari data hasil FFT dilakukan proses Band-Pass Filter, yaitu sebuah proses yang akan menyaring gelombang yang ada di zona tersebut hingga hanya tersisa data gelombang dengan periode sebesar 30300 sekon. Proses perhitungan tinggi gelombang yang didasarkan dari rumus 2 dibawah ini.

$$
P=0.57\left(H_{s}\right)^{2}\left(T_{p}\right)
$$

Dengan memasukkan Significant Waveheight $\left(\boldsymbol{H}_{s}\right)$ dan data Periode dari gelombang tersebut $\left(\boldsymbol{T}_{p}\right)$, memungkinkan untuk mendapatkan energi dari setiap satuan luas dari gelombang tersebut $(P)$ (DexaWave, 2014). 
HASIL DAN PEMBAHASAN

\section{Import dan Perhitungan Data SSH}

Satelit altimetry Jason-2 menghasilkan data dengan format NetCDF. Pada penelitian ini data diolah dengan aplikasi Basic Radar Altimetri Toolbox (BRAT) untuk proses gridding dan konversi serta Mathematic Laboratory (MATLAB). Proses konversi yang dilakukan pada aplikasi BRAT menghasilkan data dengan format ASCIl yang dapat dengan leluasa diakses oleh MATLAB maupun Excel.

Data disortir menurut cycle-nya dan ditempatkan dalam satu folder yang berisi data altimeter Jason-2 per bulan, yang kemudian diinput dalam satu dataset. Dalam proses import data ke BRAT dilakukan pendefinisian kriteria yang didalamnya terdapat pengaturan range data dan diatur untuk bulan Januari.
Komponen Sea Surface Height (SSH) merepresentasikan tinggi muka air laut terhadap geoid setelah melakukan perhitungan komponen statik dan dinamik di dalam air laut, yang mana dalam penelitian ini dapat diabaikan karena fokus penelitian adalah pada permukaan air. Proses perhitungan komponen dinamik muka air laut dilakukan pada aplikasi BRAT dengan menggunakan rumus dibawah ini.

$$
\text { SSH = altitude }- \text { corrected range }
$$

Dengan rumus ini, dapat diketahui besaran SSH setiap titik pengamatan satelit. Dalam penelitian ini, tinggi SSH menggunakan geoid sebagai tinggi referensi. Proses penghitungan dilakukan dengan perangkat lunak BRAT (Gambar 3).

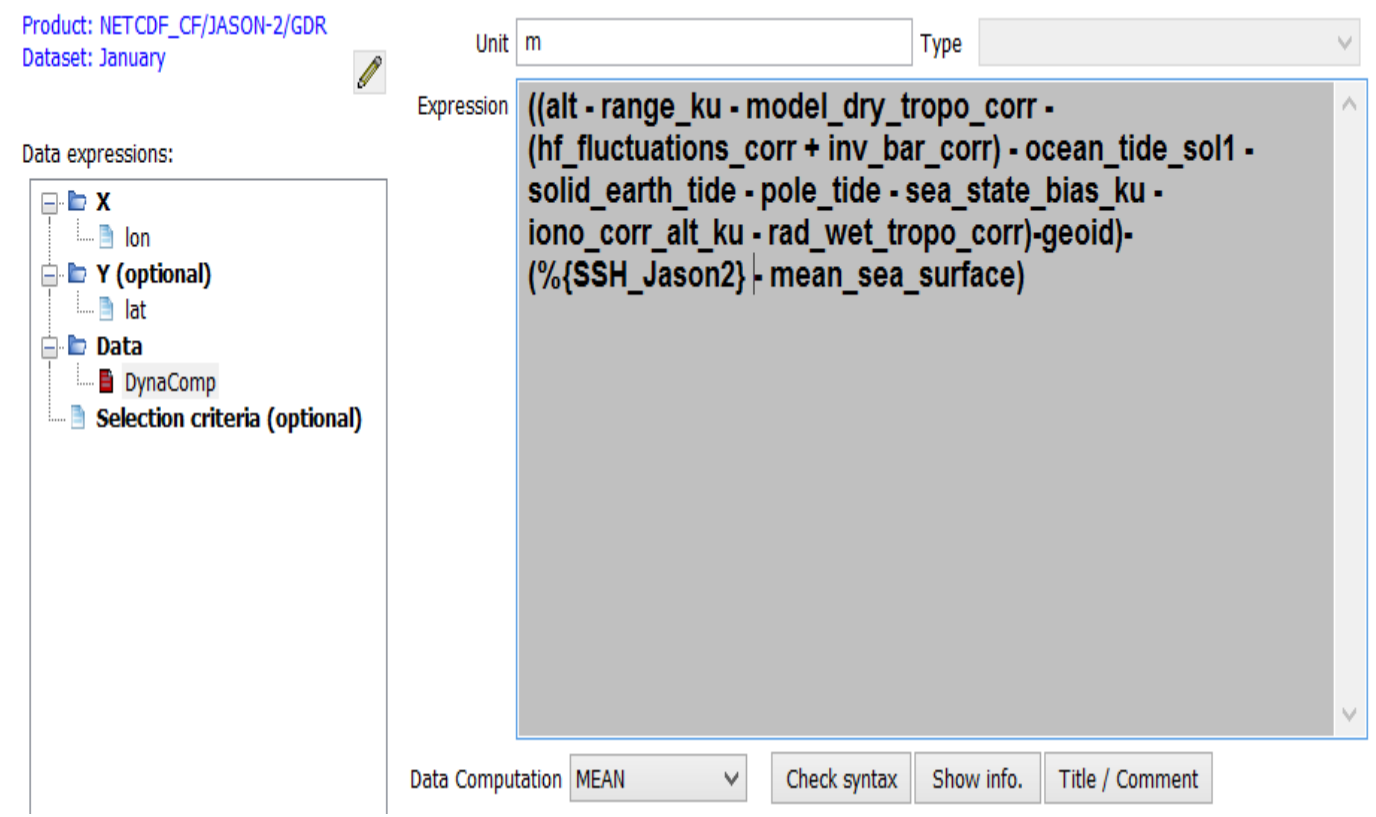

Gambar 3. Proses Perhitungan SSH pada BRAT

\section{Filtering dan Gridding data Jason-2}

Dalam tahap konversi data juga terdapat filter atau penyaringan data, dengan parameter BRAT sebagaimana tercantum dalam Tabel 2. Tujuan dari proses ini adalah untuk menyaring sejumlah data dari beberapa satelit altimetri sehingga hanya akan didapatkan data satelit altimetri Jason-2 saja karena tidak menutup kemungkinan bahwa data input adalah data gabungan dari beberapa satelit altimetri yang dapat tumpang tindih. Pada proses konversi data menggunakan aplikasi BRAT, dilakukan filter pada data sehingga data sesuai dengan kriteria satelit. AVISOO dan PODAAC merekomendasikan filter kriteria satelit Jason-2 dengan parameter sebagai berikut. 
Tabel 2. Recommended Filter Criteria Jason-2

\begin{tabular}{ll}
\hline Parameter & Validity Conditions \\
\hline range_numval_ku & $10 \leq x$ \\
range_rms_ku & $0 \leq x(\mathrm{~mm}) \leq 200$ \\
altitude-range_ku & $-130000 \leq x(\mathrm{~mm}) \leq 100000$ \\
model_dry_tropo_corr & $-2500 \leq x(\mathrm{~mm}) \leq-1900$ \\
rad_wet_tropo_corr & $-500 \leq x(\mathrm{~mm}) \leq-1$ \\
iono_corr_alt_ku & $-400 \leq x(\mathrm{~mm}) \leq 40$ \\
sea_state_bias_ku & $-500 \leq x(\mathrm{~mm}) \leq 0$ \\
ocean_tide_sol1 & $-5000 \leq x(\mathrm{~mm}) \leq 5000$ \\
solid_earth_tide & $-1000 \leq x(\mathrm{~mm}) \leq 1000$ \\
pole_tide & $-150 \leq x(\mathrm{~mm}) \leq 150$ \\
swh_ku & $0 \leq x(\mathrm{~mm}) \leq 11000$ \\
sigO_ku & $7 \leq x(\mathrm{~dB}) \leq 30$ \\
wind_speed_alt & $-0 \leq x(\mathrm{~m} / \mathrm{s}) \leq 30$ \\
off_nadir_angle_wf_ku & $-0.2 \leq x(\mathrm{deg}) \leq 0.64$ \\
sigO_rms_ku & $x(\mathrm{~dB}) \leq 1$ \\
sigO_numval_ku & $10<x$
\end{tabular}

Data SSH Indonesia yang telah di-gridding sebesar $0.25 \times 0,25$ derajat dan dibagi menjadi 2 zona. Proses cropping dilakukan pada aplikasi Matlab dengan matriks 2 dimensi yang dianggap mewakili kriteria laut daerah tersebut. Kemudian data SSH tersebut dibagi lagi menjadi data perbulan dimana setiap bulan merepresentasikan tinggi muka air laut rata-rata pada bulan tersebut. Dengan cara ini, diharapkan akan didapatkan kemungkinan terbesar daerah yang berpotensi sebagai daerah potensi pembangkit listrik gelombang laut dengan melakukan perbandingan data setiap bulan.

Zona A yang yang digambarkan oleh Gambar 4 dalam bentuk 2 dimensi dan Gambar 5 dalam bentuk 3 dimensi adalah wilayah perairan Samudra Hindia sebelah selatan pulau Jawa dengan besar dimensi $2^{\circ} \times 13,5^{\circ}$, memiliki 8 kolom matriks dan 62 baris matriks dengan jarak antar matriks/data adalah sebesar $0,25^{\circ}$.

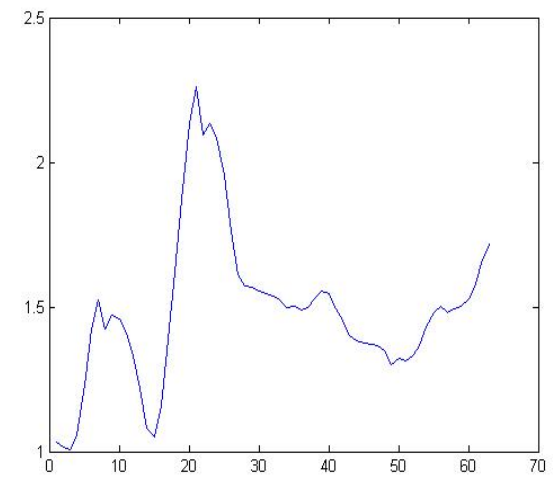

Gambar 4. Data SSH Perairan Selatan Pulau Jawa Bulan Januari

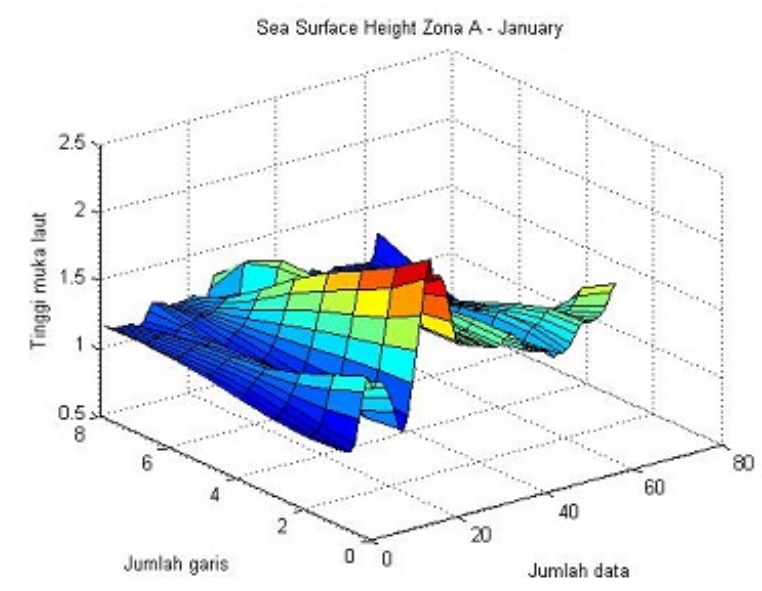

Gambar 5. Data 3 Dimensi SSH Perairan Selatan Pulau Jawa Bulan Januari

\section{Proses FFT, Relasi Dispersi dan Band Pass Filter}

Proses FFT dilakukan terhadap data SSH yang mana pada perhitungan ini biasa disebut dengan data amplitudo untuk mendapatkan nilai panjang gelombang dominan dari data SSH setiap daerah yang telah di cropping.

Nyguist haruslah ditentukan pada proses FFT ini untuk mempermudah interpretasi hasil FFT dan mencari panjang gelombang dominan. Hasil dari perhitungan panjang gelombang dominan didapatkan 2 panjang gelombang dominan, yaitu L1 sebesar 2319,2083 meter dan L2 sebesar 
4638.4167 meter yang ditunjukkan pada gambar 4.31 dan 4.32. Grafik FFT ditunjukkan pada gambar 4.29 dan 4.30. Setelah itu rumus relasi dispersi diturunkan untuk mendapatkan periode dari setiap panjang gelombang dominan yang sudah didapatkan, dan didapatkan hasil periode 1 sebesar 33.7480 sekon dan periode 2 sebesar 74.9808 sekon. Dari penurunan rumus tersebut dapat dibuktikan bahwa gelombang dominan pada area tersebut masih masuk pada kategori swell atau gravity waves yang memiliki batas 30-300 sekon.

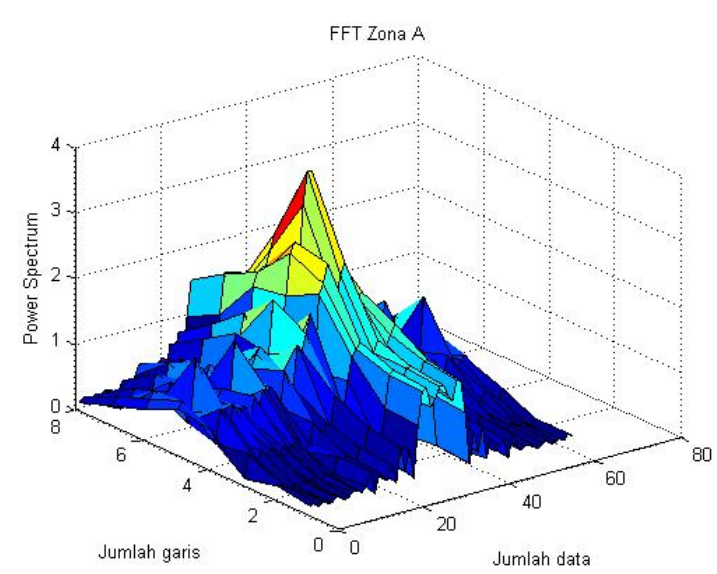

Gambar 6. Hasil FFT 2 Dimensi

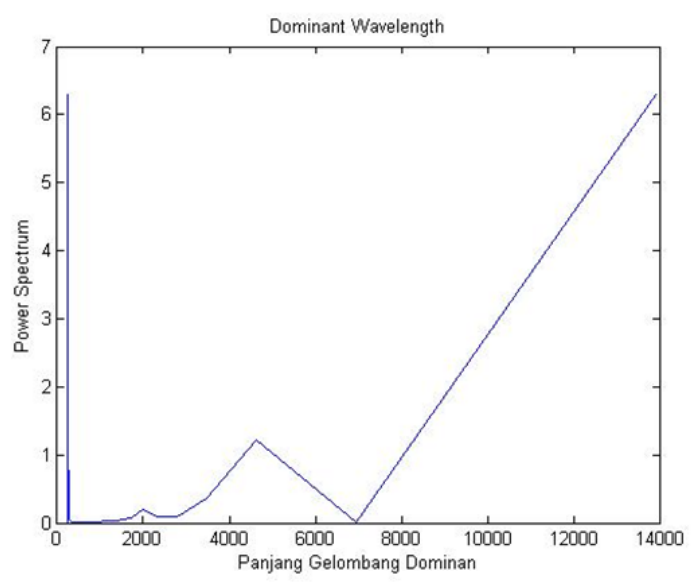

Gambar 7. Dominant Wavelenght

Selanjutnya proses Band-Pass Filter dilakukan kepada data FFT yang tujuannya untuk menyeleksi gelombang agar sesuai dengan filter kriteria swell atau gravity waves yang mempunyai periode atau $t$ sebesar 30-300 sekon. Band-Pass Filter sangat dibutuhkan karena ada banyak sekali gelombang yang merambat di laut lepas sehingga dibutuhkan proses seleksi terhadap spektrum gelombang itu sendiri.

Desain filter ini dibuat dengan metode trial dan error menggunakan teori relasi disperse dimana apabila besaran panjang gelombang L2 sebesar 4638.4167 meter akan didapatkan periode sebesar 74,583 sekon. Sehingga untuk mendapatkan periode sebesar 30-300 sekon, apabila dikonversi menggunakan rumus relasi dispersi, akan didapatkan panjang gelombang Lmin sebesar 868.78 meter dan Lmax sebesar 9384.48 meter sebagai batas bawah dan atas filter. Proses ini dilakukan pada spektrum gelombang 1 dimensi.

Proses konvolusi dilakukan untuk menyeleksi nilai yang masuk dalam kriteria filter yang sudah dibuat sebelumnya. Proses inversi FFT dilakukan terhadap hasil dari konvolusi sehingga data kembali menjadi gelombang laut.

Hasil inverse FFT (IFFT) tersebut lalu dikonversi menuju Amplitudo yang nantinya dapat digunakan untuk menghitung intensitas energi di setiap titik.

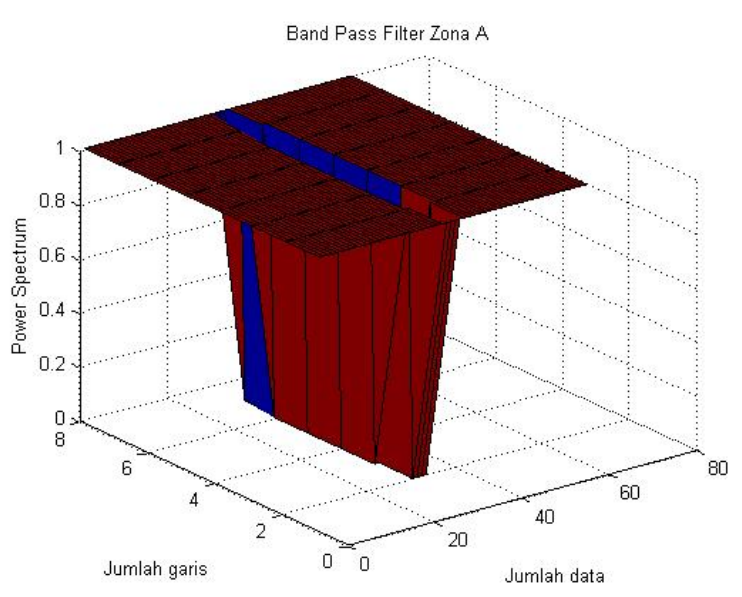

Gambar 8. Band-Pass-Filter Design 


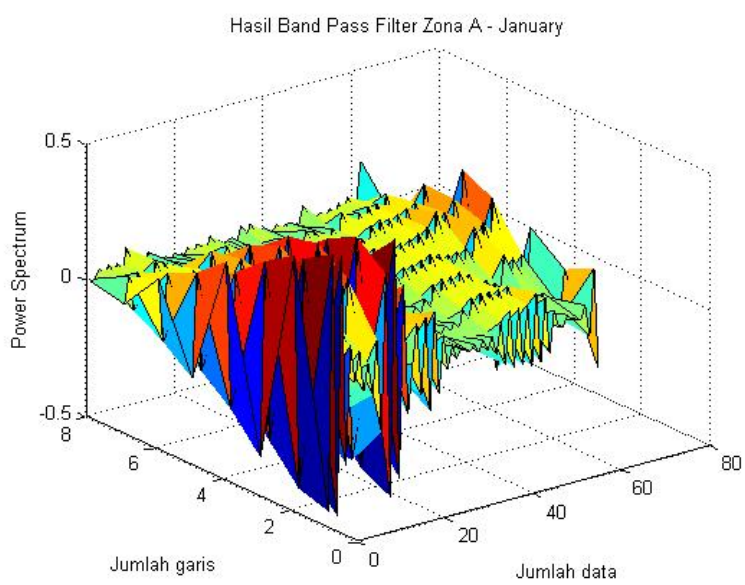

Gambar 9. Hasil Band-Pass-Filter - Januari

\section{Perhitungan Intensitas Energi}

Data amplitudo yang telah didapatkan sebelumnya akan diolah menggunakan rumus intensitas energi untuk menghitung nilai wave power dari setiap titiknya. Wave power ini menunjukkan intensitas energi per satuan luas dalam satuan watt atau watt-per-meter ${ }^{2}$. Wave power pada bulan Januari disajikan pada Gambar 10.

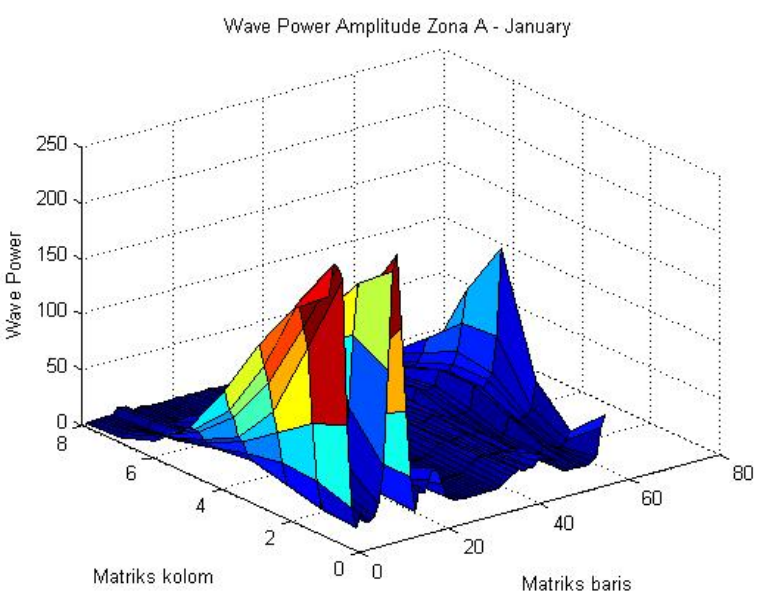

Gambar 10. 2D Wave Power Amplitude - Januari

Gambar 11 di bawah adalah peta estimasi energi pada bulan Januari 2012. Pada gambar bahwa terdapat 3 titik potensial Zona A dengan besar maksimal 241,6539 W. Titik-titik potensial pada Zona A terdapat di:

- Selatan Selat Sunda sekitar koordinat (104,312591 BT - 7,131788 LS) dengan estimasi energi sebesar 241,6539 $\mathrm{W} / \mathrm{m}^{2}$;

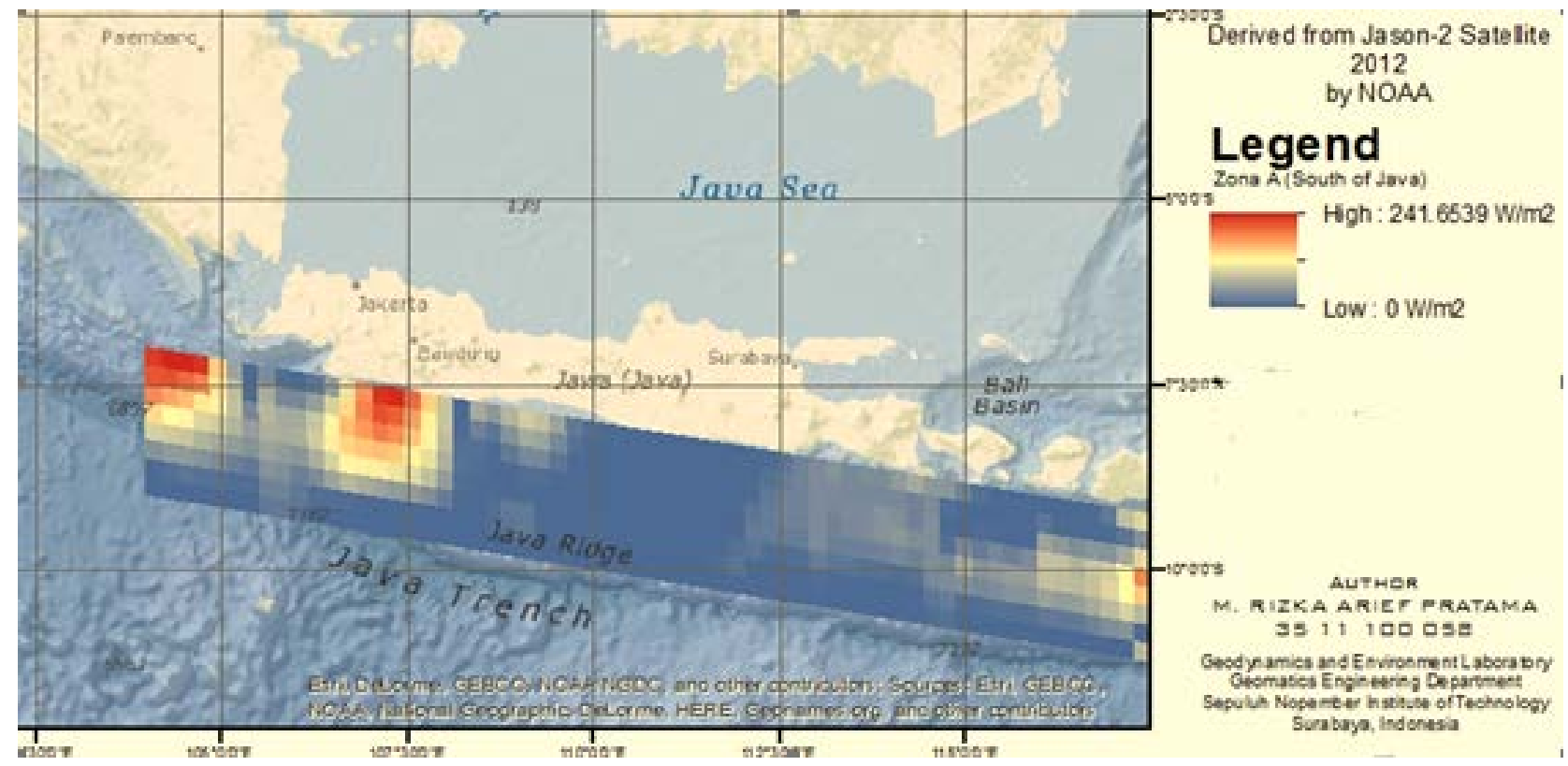

Gambar 11. 1 Wave Energy Estimation Map January

- Selatan Pulau Jawa sekitar koordinat $(107,243195$ BT - 7,666942 LS) dengan estimasi energi sebesar $234,7495 \mathrm{~W} / \mathrm{m}^{2}$; serta
- Selatan Nusa Tenggara Barat sekitar koordinat (117,385634 BT - 10,113359 LS) dengan estimasi energi sebesar $188,3914 \mathrm{~W} / \mathrm{m}^{2}$. 
Tabel 3. Besaran Estimasi Energi di Setiap Titik Potensial

\begin{tabular}{llll}
\hline Bulan & $\begin{array}{c}\text { Selatan Selat } \\
\text { Sunda }\end{array}$ & Selatan Jawa & \multicolumn{1}{c}{$\begin{array}{c}\text { Selatan } \\
\text { NTB }\end{array}$} \\
\hline Januari & 241,6539 & 234,7495 & 188,3914 \\
Februari & 123,4587 & 160,5405 & 94,6274 \\
Maret & 169,5217 & 178,8588 & 125,9165 \\
April & 110,7012 & 147,2027 & 141,839 \\
Mei & 102,9303 & 158,4503 & 133,839 \\
Juni & 109,9278 & 149,624 & 141,074 \\
Juli & 82,9097 & 134,5937 & 110,3668 \\
Augustus & 93,5153 & 122,4376 & 48,6858 \\
September & 115,8602 & 134,5937 & 119,3733 \\
Oktober & 112,6044 & 156,9078 & 113,2197 \\
November & 133,2939 & 133,2963 & 234,7495 \\
Desember & 143,8928 & 234,7495 & 194,2556 \\
Rata-rata & 128,355825 & 162,1670333 & 137,194833 \\
Maksimal & 241,6539 & 234,7495 & 234,7495 \\
Minimal & 82,9097 & 122,4376 & 48,6858 \\
\hline
\end{tabular}

Tabel di atas merupakan besaran energi dari 4 daerah potensial setiap bulan selama satu tahun 2012. Spot-1 adalah daerah sebelah Selatan Selat Sunda, spot-2 adalah Selatan Jawa, spot-3 adalah lautan di Selatan NTB dan spot- 4 adalah lautan di sebelah Barat pulau Sumatra. Data ini didapatkan dari overlay hasil olahan estimasi energi pada aplikasi Matlab.

Dari tabel di atas dapat diestimasi deposit energi gelombang maksimal di setiap titik potensial di setiap bulannya:

- pada bulan Januari, keluaran energi paling tinggi untuk daerah di Selatan Selat Sunda dan Selatan Pulau Jawa;

- pada bulan Desember, keluaran energi paling tinggi untuk lautan Selatan NTB dan Barat Pulau Sumatra ;

- pada bulan Juli dan Agustus, dapat diasumsikan sebagai bulan penghasil energi paling rendah;

- antara bulan November-Maret didapatkan pasokan energi gelombang air laut paling optimal atau biasa disebut sebagai periode produktif.

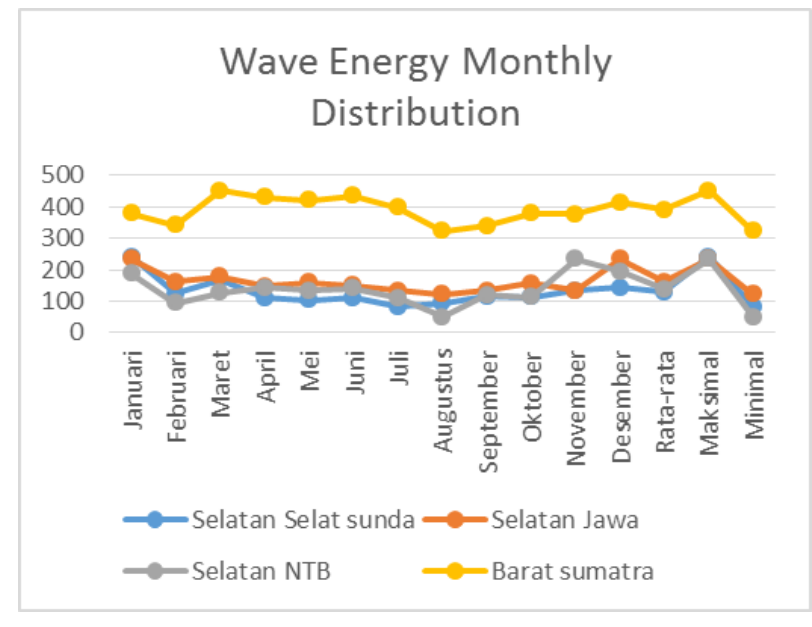

Gambar 12. Distribusi Energi Setiap Bulan

Spot-3 memiliki potensi energi yang lebih tinggi dibandingkan dengan spot-1, spot-2 dan spot-4. Salah satu faktor penyebab yang saya dapatkan dari penelitian ini adalah besarnya perbedaan tinggi antara SSH paling tinggi dengan SSH paling rendah pada zona-B. Faktor lain yang mungkin terjadi adalah akibat dari proses interpolasi yang mengakibatkan tinggi permukaan laut terpengaruh daratan, hal ini diakibatkan satelit Altimetri Jason-2 juga mendapatkan data tinggi daratan.

\section{PENUTUP \\ Simpulan}

Data Sea Surface Height dari Satelit Altimetri dapat digunakan untuk mengukur tinggi, panjang, periode, dan amplitude gelombang hingga mendapatkan energi per satuan luas yang mana sebelumnya dibutuhkan pre-processing, fast fourier transform dan band-pass filter yang dapat dikerjakan menggunakan MATLAB.

Proses gridding dan interpolasi dapat dilakukan pada BRAT namun hasilnya tidak cukup baik dan tidak dianjurkan untuk sebuah penelitian yang teliti. Namun pada preliminary estimation seperti pada penelitian ini kesalahan pada proses ini masih dapat ditoleransi karena hasil yang didapatkan masih berupa estimasi dan dibutuhkan penelitian kedepannya. 
Estimasi energi yang didapatkan dari penelitian ini dapat dilihat pada Gambar 12 yang mana dapat diketahui bahwa terdapat 3 daerah potensial yang memiliki estimasi energi gelombang air laut yang cukup tinggi dibandingkan dengan daerah lainnya yaitu:

1. Selatan Selat Sunda dengan koordinat sekitar 107,211001 BT - 7,644222 LS, memiliki estimasi energi maksimal pada bulan Januari sebesar $241,6539 \mathrm{~W} / \mathrm{m}^{2}$, minimal sebesar 82,9097 $\mathrm{W} / \mathrm{m}^{2}$ pada bulan Juli dan rerata sebesar $128,3558 \mathrm{~W} / \mathrm{m}^{2}$.

2. Selatan Pulau Jawa dengan koordinat sekitar 107,373590 BT - 7,667449 LS, memiliki estimasi energi maksimal pada bulan Januari sebesar $234,7495 \mathrm{~W} / \mathrm{m}^{2}$, energi minimal sebesar $122,4376 \mathrm{~W} / \mathrm{m}^{2}$ pada bulan Agustus dan memiliki rerata sebesar $162,1670 \mathrm{~W} / \mathrm{m}^{2}$

3. Perairan Selatan Nusa Tenggara Barat dengan koordinat sekitar 117,407642 BT - 9,339791 LS memiliki estimasi energi maksimal pada bulan November sebesar $234,7495 \mathrm{~W} / \mathrm{m}^{2}$, minimal sebesar $48,6858 \mathrm{~W} / \mathrm{m}^{2}$ dan rerata sebesar 137 , $1948 \mathrm{~W} / \mathrm{m}^{2}$

\section{Saran}

Sangat diperlukan penelitian lanjutan yang lebih akurat seperti pengamatan insitu untuk memastikan nilai potensi energi gelombang laut dari hasil estimasi penelitian ini. Alat-alat seperti buoy dan currentmeter sangat dianjurkan.

Data pembanding/sekunder dari hasil pengamatan langsung di lapangan seperti data SSH, arus, dan angin sangat diperlukan untuk proses validasi penelitian ini

\section{DAFTAR PUSTAKA}

AM, Muzathik, Wan Nik WB, Ahmad MF, and Samo KB., 2011. Wind energy potential at East Coast of Peninsular Malaysia. International Journal of Applied Engineering Research, Dindigul.

A. S. E. J. H. W. M. T. P. J. T.-M. Lewis, 2011. Ocean Energy dalam IPCC Special Report on Renewable Energy Sources and Climate Change Mitigation, Cambridge, Cambridge University Press, pp. 497-534.
AM, Muzathik, Wan Nik WB, Ahmad MF, and Samo KB. 2011. Wind energy potential at East Coast of Peninsular Malaysia, International Journal of Applied Engineering Research, Dindigul .

DexaWave, 2014. Energy Content. October 22. http://www.dexawave.com/energy-content.html.

Kementrian Kelautan dan Perikanan Republik Indonesia, Keanekaragaman Hayati Laut Indonesia Terbesar di Dunia. 28 August 2013. [Online]. Available: http://kkp.go.id.

Seeber, Gunter., 1993. Satellite Geodesy. Berlin: GmbH and $\mathrm{Co}$. 
Halaman ini sengaja dikosongkan 